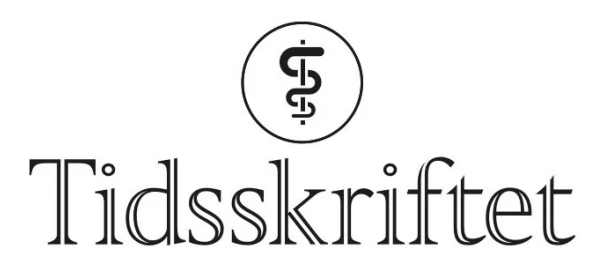

DEN NORSKE LEGEFORENING

\title{
Nyretransplantasjon før og nå
}

\section{LEDER}

KRISTIAN HELDAL

hkri@ous-hf.no

Kristian Heldal er ph.d., spesialist i generell indremedisin og nyresykdommer og seksjonsoverlege ved Avdeling for transplantasjonsmedisin ved Oslo universitetssykehus.

Forfatteren har fylt ut ICMJE-skjemaet og oppgir ingen interessekonflikter.

\section{Norge har et nyretransplantasjonsprogram av høy kvalitet takket være godt samarbeid mellom alle landets sykehus og Oslo universitetssykehus. Den største utfordringen er for liten tilgang på organer i forhold til behovet.}

Det første forsøket på å transplantere nyre mellom mennesker ble utført i Ukraina så tidlig som i 1933, men det var først i 1954 at den første vellykkede nyretransplantasjonen ble gjennomført. Det skjedde i Boston, og operasjonen ble ledet av Joseph Murray (1919-2012) (1). Etter dette gikk det bare to år før professor Leif Efskind (1904-87) ved Rikshospitalet gjennomførte den første nyretransplantasjonen i Norge (므). I perioden 196o-62 ble ytterligere fire pasienter transplantert på Rikshospitalet, men samtlige døde etter mellom 14 og 40 dager på grunn av sepsis eller avstøting. Den første vellykkede nyretransplantasjon i Norge ble utført ved Ullevål sykehus i 1963(므).

I Tidsskriftet presenterer nå Sara Namek og medarbeidere resultatene for 118 pasienter transplantert ved Ullevål sykehus mellom 1963 og 1983 (3). De beskriver en pionertid i norsk medisinsk historie som var grunnlaget for at vi i Norge i dag har et nyretransplantasjonsprogram som kjennetegnes av høy kvalitet og tilgjengelighet for alle uavhengig av bosted.

Fra 1983 har alle transplantasjoner blitt utført ved Rikshospitalet. Den norske modellen med ett nasjonalt transplantasjonssenter sikrer et stort erfaringsgrunnlag og enhetlig utredning og behandling av pasientene før, under og etter transplantasjonen. All utredning av pasienter og potensielle levende givere skjer derimot på lokalsykehus. Etter transplantasjonen blir pasientene fulgt i seks til åtte uker ved Oslo universitetssykehus, før de overføres til sitt lokalsykehus for livslang oppfølging. Ved transplantasjonsrelaterte problemer tas det kontakt med nyrelege ved Oslo universitetssykehus. Dette samarbeidet baserer seg på engasjement for fagfeltet og gjensidig tverrfaglig kommunikasjon. 
For oss som driver transplantasjonsvirksomhet i $2021 \mathrm{er} \mathrm{det} \mathrm{vanskelig} \mathrm{å} \mathrm{tenke} \mathrm{seg} \mathrm{hvordan}$ man kunne gjennomføre transplantasjoner uten avanserte immundempende medikamenter og kunnskap om HLA-vevstyper. Introduksjonen av ciklosporin som immundempende legemiddel i 1983 medførte betydelig forbedrede resultater med en $\emptyset \mathrm{kning}$ av ettårs transplantatoverlevelse fra ca. 50 \% til over 70 \%. Senere er det utviklet flere immundempende medikamenter, og vi har lært mer om hvordan de bør doseres for å få best mulig resultat. Dette, sammen med framskritt innenfor kirurgi og immunologi, har ført til at dagens ettårs transplantatoverlevelse er over 95\% (4). I tillegg til overlevelsesgevinsten opplever også de fleste pasientene bedret livskvalitet etter transplantasjon sammenlignet med dialysebehandling.

\section{«Det siste tiåret har ventelistene for nyretransplantasjon doblet seg»}

Organtransplanterte pasienter lever altså lenger enn de gjorde før. Dette har skapt nye utfordringer. Nyretransplanterte har økt sykelighet og dødelighet på grunn av hjertekarsykdom, kreft og infeksjonssykdommer. I begynnelsen av covid-19-pandemien ble det rapportert at nyretransplanterte hadde betydelig økt covid-19-relatert dødelighet (5). Transplanterte har også dårligere effekt av vaksinen. Kun 30 \% oppnår beskyttende antistoffnivå etter to doser, mens man etter tre doser nærmer seg en responsrate på 50 \% (ㅁ). En fjerde vaksinedose utforskes nå for å bedre responsen ytterligere. På grunn av dårlig vaksinerespons er mortaliteten for fullvaksinerte nyretransplanterte med covid-19 dessverre fortsatt høy.

En av våre største utfordringer i dag er ubalansen mellom antall pasienter på venteliste og tilgangen på organer. I Norge hadde vi lenge stabile og korte ventelister. Det siste tiåret har imidlertid ventelistene for nyretransplantasjon doblet seg fra rett under 200 pasienter i 2011 til rett over 400 ved utgangen av 2020. En nylig vedtatt metode for donasjon etter hjerte- og respirasjonsstans kan trolig medføre 20-30 ekstra nyrer per år (7.). I tillegg er det i Scandiatransplant, den nordiske utvekslings- og samarbeidsorganisasjonen for organtransplantasjoner, etablert en utvekslingsordning for nyrer fra levende givere. Gjennom denne ordningen er det utført flere vellykkede transplantasjoner i Sverige og Danmark. Forhåpentligvis kan også norske pasienter få dette tilbudet i 2022.

Det er en målsetting å tilby nyretransplantasjon til alle pasienter som vil ha nytte av en ny nyre. I Norge har vi akseptert mer komorbiditet enn i de fleste andre transplantasjonsprogrammer, og vi har heller ingen øvre aldersgrense for transplantasjon er man frisk nok, så er man ung nok. Men også dialyse og medikamentell behandling av pasienter med nyresvikt har blitt bedre de senere årene. Noen pasienter, spesielt de med mye komorbiditet, kan ha vel så gode resultater ved livslang dialysebehandling som ved nyretransplantasjon. Vurdering av hvilken behandling som er best for den enkelte pasient, er svært utfordrende og krever god og oppdatert kunnskap om forhold som påvirker resultatene.

Dagens transplantasjonsvirksomhet er ressurskrevende. Den er likevel samfunnsøkonomisk svært gunstig, da en transplantert pasient fører til mye lavere kostnader enn en pasient i dialyse. Et juleønske er derfor å få tilstrekkelige ressurser til å videreutvikle det nasjonale transplantasjonsprogrammet slik at vi også i fremtiden kan levere transplantasjonsresultater i verdenstoppen.

\section{LITTERATUR}

1. Merrill JP, Murray JE, Harrison JH et al. Successful homotransplantation of the human kidney between identical twins. J Am Med Assoc 1956; 160: 277-82. [PubMed][CrossRef]

2. Reisaeter AV. Nyretransplantasjon i Noreg-eit historisk perspektiv. Tidsskr Nor Lægeforen 1999; 119: 3163-6. [PubMed] 
3. Namek S, Schweder T, Lie M. Pasienter nyretransplantert ved Ullevål sykehus 1963-83. Tidsskr Nor Legeforen 2021; 141. doi: 10.4045/tidsskr.20.0579. [CrossRef]

4. Annual report Norwegian Renal Registry 2019. Oslo: Norsk Nyreregister, 2020. https://www.nephro.no/nnr/A_RSRAPPORT_NNR_2019.pdf Lest 12.11.2021.

5. Jager KJ, Kramer A, Chesnaye NC et al. Results from the ERA-EDTA Registry indicate a high mortality due to COVID-19 in dialysis patients and kidney transplant recipients across Europe. Kidney Int 2020; 98: 1540-8. [PubMed][CrossRef]

6. Benotmane I, Gautier G, Perrin P et al. Antibody response after a third dose of the mRNA-1273 SARS$\mathrm{CoV}-2$ vaccine in kidney transplant recipients with minimal serologic response to 2 doses. JAMA 2021; 326: 1063-5. [PubMed][CrossRef]

7. Giske L, Solberg B, Tranvåg E et al. Organdonasjon med bruk av normoterm regional perfusjon hos pasienter som dør av hjerte- og åndedrettsstans når livsforlengende behandling avsluttes. Rapport 2019. Oslo: Folkehelseinstituttet, 2019. https://www.fhi.no/en/publ/2019/Organ-donation-with-the-useof-normothermic-regional-perfusion/ Lest 12.11.2021.

Publisert: 13. desember 2021. Tidsskr Nor Legeforen. DOI: 10.4045/tidsskr.21.0779

(C) Tidsskrift for Den norske legeforening 2023. Lastet ned fra tidsskriftet.no 26. april 2023. 